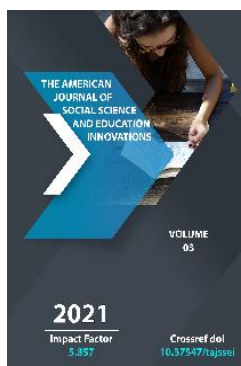

\title{
Integral Structure Of Professional I-Concept
}

Muminov Shemuhammad Karimovich

Senior Lecturer Of The Institute For Retraining And Advanced Training Of Directors And Specialists of Preschool Education Institutions, Tashkent, Uzbekistan

Journal Website:

http://theamericanjour

nals.com/index.php/taj

ssei

Copyright: Original content from this work may be used under the terms of the creative commons attributes 4.0 licence.

\section{ABSTRACT}

The paper considers the notion of "professional self-concept". Its multilevel structure, in which components, modalities, levels, time components and distorting components are identified and described, is represented and substantiated. Professional self-concept is considered as a structural analogue of the general self-concept and the marked difference in the structures of the concepts is showed.

\section{KEYWORDS}

Professional self-concept; structure; components; modalities; levels.

\section{INTRODUCTION}

The relevance of the scientific development of the problem of the professional self concept is due both to its significance for understanding the mechanisms of the formation of a professionally realized personality, and to the ambiguity of approaches to the interpretation 
of this concept. This led to an attempt to systematize the ideas of the professional selfconcept, to describe its structure. An analysis of the literature available to us showed that there is no holistic idea of the professional self-concept, only individual components of the phenomenon under consideration have been studied, while much attention is paid to the study of the features of professional selfconcepts in specific areas of activity, and not the content of the concept as a whole. However, in a number of works [1; five; 20, etc.] the tendency of the search for the system-forming factor of the studied phenomenon, its purpose, integral characteristics and typology is indicated.

Along with the term "professional selfconcept", today such concepts as "real selfprofessional", "personal construct Iprofessional", "self-model of a professional", "subjective picture of the professional path", "professional self-image" are used. , "A holistic image of myself as a professional" or "I am a professional" [5; eight; 10; 13; fifteen; sixteen; 12].

However, the term "professional selfconcept" has a greater certainty: its operationalization occurs through its use in an increasing number of studies.

We take the definition of S.T. Dzhaneryan as the basis of the concept and understand the professional self-concept as a dynamic system of self-perceptions associated with evaluations, uniting the interaction of various images of oneself, reflecting the properties of a person as a subject of professional activity and as a person, correlated with the characteristics of activity, relationships with the social and professional community, the person's own formation in his professional career [5].

The professional self-concept has a similar structure to the structure of the general selfconcept, however, if the self-concept refers to the personality as a whole, then the professional self-concept affects the personality as a subject of professional activity.

As a result of generalization and systematization of various views on the structure of the self-concept, we have identified the following components:

- Components: cognitive, emotional-value and behavioral;

- Modalities: real I, mirror I, ideal I;

- Levels / aspects of I: physical, social, personal (includes spiritual, material, existential, mental and emotional aspects);

- Temporal components: I-past, I-present, Ifuture, I-dynamic, I-possible and working Iconcepts;

- Distorting components of the selfconcept: idealized self, represented / presented self, false self.

The types of components identified by us in the structure of the self-concept in relation to the professional self-concept have not been studied in equal detail.

Thus, the components of the professional selfconcept: cognitive, emotional-value and behavioral, are in the focus of researchers' attention, although they have been studied unequally. The most studied is the cognitive component, less - the emotional-evaluative component of the professional self-concept, the behavioral component has been studied even less, and the first two components are studied separately from the behavioral one [1].

We will define the cognitive component of the professional self-concept as an idea of oneself as a professional, the emotional component 
as a system of professional self-assessments, and the behavioral component as a manifestation of ideas about oneself and selfassessments in professional behavior. In traditionally organized research, the $\mathrm{Y}$ concept is studied with the help of statements, lists of qualities, self-descriptions, projective methods given by the researcher. The data obtained in this way makes it possible to reveal structurally the cognitive and emotional and evaluative components. Methods for studying the behavioral component of the self-concept are not presented in the literature. Its intentional aspect is only indirectly noted in the study of self-attitude as a level of internal actions towards oneself or readiness for such actions. And the other three aspects of the behavioral component (action, proper behavior and selfregulation) are studied outside the framework of the self-concept. Thus, there is a deficit in the study of the behavioral component of the self-concept [1].

The cognitive component, denoted in the psychological literature as knowledge or ideas about oneself, the descriptive component, self-understanding, acts as a priority in the study of the professional self-concept, plays a leading role in conditioning the selfdevelopment of a person in professional activity, and its dynamics reflects the characteristics of the process of professionalization and is one of the criteria for its success $[5 ; 14 ; 17]$. The content of the cognitive component of a person's professional self-concept, along with the level of development of his professional qualities and professional role, includes ideas about the presence and severity of professional and personal properties in other professionals, about the process, result, achievements, subject, conditions, means, modes, remuneration, norms, rules, models of their profession, serving as a standard for a person's awareness of his own qualities, about external factors affecting his personality [3; 4; 5; 12; 13; 21; 23].
The content of the cognitive component of the self-concept is influenced by professional affiliation, gender, stage of professionalization, length of service and the nature of involvement in the profession, the attitude of subjects to the profession $[5 ; 7 ; 13$; 22].

The cognitive component includes not only ideas about their professionally relevant qualities, but also professional self-efficacy (the idea of an individual that he is able to demonstrate such behavior that will allow him to achieve the desired results in the profession and work), ideas about professional orientations (ideas about one's abilities, value orientations, motives, meanings and needs related to promotion in professional activity), ideas about career and work (needs in building a career, career goals and strategies, the presence of a tendency to manage their career, as well as the identification of criteria for a successful career, the dynamics of career processes) [2; $18 ; 20 ; 28]$.

We understand the emotional component of the professional self-concept as a system of professional self-assessments, or assessments of oneself as a professional. Also, this component includes a sense of professional relevance (subjective attitude of the individual to himself as to "Significant for Others") [20; 26].

Considering professional self-esteem as an education, on which the professional success of an individual largely depends, A.A. Rean professional level and level of competence) and personal (expressed in the assessment of their personal qualities in connection with the ideal of the image of "I am professional") aspects. Self-assessment on these two aspects is not necessarily consistent. Its mismatch in the selected aspects affects professional adaptation, professional success and professional development of the 
individual. In the structure of professional selfesteem, the following are distinguished:

- Self-assessment of the result, which is associated with the assessment of the achieved (in general and partial aspects) and reflects the satisfaction / dissatisfaction with the achievements;

- Self-assessment of potential, associated with the assessment of their professional capabilities and reflecting confidence in their abilities.

Low self-esteem of the result does not necessarily mean a "professional inferiority complex". On the contrary, in combination with a high self-esteem of potential, it is a factor in the professional self-development of an individual [19].

The behavioral component of the professional self-concept is defined as a set of actions and attitudes towards these actions in relation to the personality and its professional development, it is directly formed on the basis of the cognitive and emotional-evaluative components [1]. The behavioral component, according to IV Afanasenko, is substantively represented by strategies for building a professional career and is a specific system of actions designed to adapt or develop the career itself and the person in it [1].

Even less studied are the modalities of the professional self-concept: professional real self, professional mirror self, professional ideal I. A. A. Rean distinguishes real and ideal components in the concept of professional self-concept. A real professional concept of oneself is a person's idea of oneself as a professional, while the ideal self-concept corresponds to professional desires and hopes [19]. As in the case with the modalities of the general self-concept, the real and ideal professional self-concepts not only may not coincide, but in most cases necessarily differ, and their discrepancy is a source of professional self-improvement of the individual and his desire for development [19], although, with on the other hand, the mismatch between the real and the ideal self can become a source of serious intrapersonal conflicts [6]. An indicator of progressive professional development and selfdevelopment is the structure of selfassessments, in which the actual selfassessment is higher than the retrospective one, and the ideal one is higher than the actual one [9]. The relationship between the real and the ideal self in the course of a person's professional development depends on the conditions, work experience, and attitude towards it [5]. An empirical indicator of the degree of subjective acceptance of the profession is the correlation coefficient between the qualities attributed by a person to himself as a professional and the qualities that characterize his ideal self [25].

The professional mirror self reflects a person's ideas of how others see him. It performs the function of self-correction of a person's professional aspirations and his ideas about himself. This feedback mechanism helps to keep the real self within adequate limits and to remain open to new experience through reciprocal dialogue with others and with oneself. The mismatch between the I-real and the I-mirror, up to their complete independence, is regarded as the presence of an excessive egocentric attitude and denial of other points of view and positions, which leads to instability, inconsistency of the Image of I. others, for the position "I am bad, you are good." As a result, a person's neurotic dependence on other people appears, suffering, feelings of tension, loss of his own "I", intrapersonal contradictions and difficulties in professional activity [5].

Considering the professional self-concept as a structural analogue of the general selfconcept, we approached the levels, or aspects, which represent the physical, social and personal levels. This type of components 
is a special case in comparison with other components, since the professional selfconcept is not represented by the named levels, but itself is part of one of them, namely the social one, on which the human activity we are studying is manifested. Consequently, there is a structural mismatch between the general and professional self-concepts.

Temporary, or chronological, components are presented in the structure of the professional self-concept. Professional Yconception as a subjective picture of the professional path presupposes the representation of the present, past and future in it [5; 13]. A nondynamic professional self-concept that does not contain ideas about oneself in the time perspective is regarded as a brake on the professional development of a civil servant's personality [5; eleven]. Realizing and comparing the professional I-past, I-present and I-future, a person is able to overestimate his own life path, his own destiny. The results of comparison in self-awareness of current and past motives, traits, goals can lead to a change of profession, to finding a side, unprofessional occupation, to deep disappointment and dissatisfaction with oneself [24].

Also, as a temporary component, we consider it necessary to consider the working version of the professional self-concept as an analogy with the working self-concept, which is a "selfconcept in a given time and in a given social context of interaction, as part of the general repertoire of the Self, determined at the micro- and macrosocial level "[27]. The presence of working options in the structure of the professional self-concept removes the contradiction between the idea that the selfconcept is the main personal formation, therefore, a stable structure, while, however, it cannot but be fundamentally changeable. $\mathrm{S}$. T. Dzhaneryan notes that at every given moment of life, the professional self-concept embodies a system of varying degrees of awareness, significance, temporal representation of subject-activity and personal properties, which are concretized in self-descriptions in intentional, instrumental, expressive features [5]. It is the introduction of the concept of "working version" that makes the professional self-concept a unified, at the same time flexible structure.

The distorting components of the selfconcept, namely the idealized self, the presented self and the false self, have not been found by us in the literature available to us. However, we believe that all these elements can be presented in the professional part of the personality's self-awareness as associated with inadequate professional selfesteem.

So, the analysis of the structure of the professional self-concept showed that it has a similar structure with the structure of the general self-concept, having some specific points. So, in the structure of the professional self-concept, levels / aspects are not represented, since the professional selfconcept itself is part of one of them, namely the social level, within which the studied human activity is manifested, namely its professional part.

Otherwise, the components of the professional self-concept are identical to the components of the general self-concept, while having a professional focus and look as follows:

- Components: cognitive (includes not only ideas about their professionally relevant qualities, but also professional selfefficacy, ideas about career orientations, ideas about career and work), emotionalvalue (includes professional self-esteem and a sense of professional relevance, which lies at the junction of cognitive and affective components) and behavioral; 
- Modalities: professional real self, professional ideal self, professional mirror self;

- Temporary components: professional selfpresent, professional self-past, professional self-future and working versions of professional self-concept;

- Distorting components: professional idealized self, professional presented self, professional false self.

The implementation of a systematic approach to the study of the professional $Y$-concept, the description of its structure allow the construct to be operationalized and, therefore, are the basis for its empirical research.

\section{REFERENCES}

1. Afanasenko I.V. Career building strategies as a component of the professional ICONCEPT. II Sat. materials III vseros. Congress of Psychologists. - URL: http: //hoster.metod.ru: 8082 / cpt21 / practicum / pub / friends

2. Bandura A. Theory of social learning. - SPb .: Eurasia, 2000.

3. Gorskaya G.B. Psychological problems of early professionalization // Psychological problems of personality self-realization / ed. O. G. Kuko-syana. - Krasnodar: KubGU, 1997. - P. 45-56.

4. Grigorieva T. L. Professional "I-concept" of civil servants of different levels of management: dis. ... Cand. psychol. sciences. - M., 2001 -- 166 p.

5. Djaneryan S.T. Professional I-concept: a systematic approach: dis. ... Dr. psychol. Sciences: 19.00.01. - Rostov n / a: RSL, 2006 .- 605 p.
6. Kalyuzhny A. A. Ya-concept and styles of pedagogical interaction [Electronic resource]. $\quad$ - URL: http://psyjournals.ru/articles/d8082

7. 7. Klimov E.A. The image of the world in different types of professions. $\quad$ - M.: Moscow State University, 1995 -- 224 p.

8. Kobtseva Zh. V. Efficiency of employment and features of the "I-model" of the individual // Psychology and practice. Yaroslavl: YarGu Publishing House, 1998. T. 4. - Issue. 1. - P. 243-244.

9. Koziev V.N. The structure and content of the teacher's professional consciousness // Psychological problems of the development of the professional consciousness of the teacher-practitioner. - M .: APN RSFSR, 1992. - S. 30-45.

10. Kozievskaya E.V. Professional self-esteem and motivation to achieve civil servants: psychological and acmeological model of influence // Acmeology in the system of civil servants' activity / under total. ed. A. A. Derkach. - M: Publishing house of RAGS, 1999. - S. 5-14.

11. Lotova I.P. Development of professional career of civil service personnel: author. dis. ... Dr. psychol. sciences. - M., 2004 .-$58 \mathrm{p}$.

12. Markova A.K. Psychology of professionalism. - M.: Mezhdunar. humanizes. Foundation "Knowledge", 1996. $-308 \mathrm{p}$.

13. Mironova T.L. Structure and development of professional self-awareness: author. dis. ... Dr. psychol. sciences. - M., 1999 .-$40 \mathrm{p}$.

14. Mitina L.M. Psychology of teacher's professional development: dis. ... Dr. psychol. sciences. - M., 1995 .- 408 p. 
15. Mitina L.M., Bachkov I.V. et al. Problems of professional socialization of the individual: collective monograph // ed. L. M. Mitina. Kemerovo: Department of Education of the Administration of OBLIUU, Psychological Institute of the Russian Academy of Education, 1996. - 196 p.

16. Moskalenko O.V. Conditions for the formation of effective professional identity of the personality of the leaders of educational institutions. - Astrakhan, 1998 .-- 67 p.

17. Podtsubnaya T.K. Dynamics of the cognitive components of professional selfawareness of psychology students in the learning process: dis. ... Cand. psychol. sciences. - Belgorod, 1998 .-- 150 p.

18. Study of L. G., Chiker V. A. Organizational social psychology. - SPb .: Peter, 2000.

19. Human psychology from birth to death / under total. ed. A. A. Reana. - SPb : PRIME-EVROZNAK, 2002 .- 656 p.

20. Rykiel AM Professional I-concept and professional identity in the structure of personality self-awareness. Part 2 [Electronic resource] // Psychological research: electron. scientific. zhurn. - 2011. - N 3 (17). - URL: http://psystudy.ru (date of access: 05/25/21). 0421100116 | 0034.

21. Svobodny F.K. "Professional I-Image" of an employee of the internal affairs bodies // Yearbook of the Russian psychological society. Materials 3 Vseros. Congress of Psychologists. June 25-28, 2003 - St. Petersburg: Publishing house of St. Petersburg. University, 2003. - T. 7. - S. 7276.

22. Sizova I. G. Personality and professional activity of a psychologist: social representations of various professional groups: author. dis. ... Cand. psychol. sciences. - Tver, 1999 .- 23 p.
23. Stambulova N.B. Psychology of sports career: textbook. allowance. - SPb .: "Career Center", 1999. - 368 p.

24. Stolin V.V. Self-knowledge and attitude towards oneself in the structure of personality self-awareness: dis. ... Dr. psychol. sciences. - M., 1985 -- 530 p.

25. Fedorishina I.L. Influence of the image of "I" on the characteristics of professional self-determination of a senior pupil: author. dis. ... Cand. psychol. sciences. Kiev, 1990 .-- 15 p.

26. Kharitonova E. V., Yasko B. A. Questionnaire "Professional demand for personality" (PVL): methodical. leadership. - Krasnodar: KubSU, 2009.

27. Markus, H. Possible Selves: The Interface between Motivation and the Self-Concept. / H. Markus, P. Nurius // In Yardley, K., Honess, T. (Eds). Self and Identity: Psychosocial Perspectives. - Wiley, 1987.

28. Nesdale D., Pinter K. Self-efficacy and the job-seeking activities in unemployed ethnic youth // The Journal of Social Psychology. - 2000. - Vol. 140 (5). - P. 608614. 